World Journal of Social Science Research ISSN 2375-9747 (Print) ISSN 2332-5534 (Online) Vol. 3, No. 4, 2016 www.scholink.org/ojs/index.php/wjssr

\title{
Settlement of Disputes by Way of Arbitration in Pakistan
}

\author{
Sohaib Mukhtar ${ }^{1 *}$ \\ ${ }^{1}$ Faculty of Law, the National University of Malaysia, Selangor, Malaysia \\ *Sohaib Mukhtar, E-mail: sohaibmukhtar@gmail.com
}

Received: September 29, 2016 Accepted: October 8, 2016 Online Published: October 23, 2016

doi:10.22158/wjssr.v3n4p518 URL: http://dx.doi.org/10.22158/wjssr.v3n4p518

\begin{abstract}
Arbitration is a method, through which, parties resolve their disputes; outside the court of law; by avoiding all types of technicalities of procedural law. It is one of the modes of Alternate Dispute Resolution. The Arbitration Act 1940 is the only statute in Pakistan, which deals with all types of arbitration processes in Pakistan, but it does not deal with the recognition and enforcement process of International Arbitral Awards in Pakistan. The New York Convention 1958 is enforced in Pakistan, through the Recognition and Enforcement Act 2011 and it deals with the recognition and enforcement process of International Arbitral Awards in Pakistan. The problem in Pakistan is that the majority arbitration processes are not conducted, in accordance with the provisions of the prescribed laws of arbitration, they are usually conducted, in accordance with the customs and usages of the society, which are not prescribed in the current Arbitration Act 1940. There are private Jirga and Punchayat systems; in rural areas; throughout Pakistan, to resolve disputes of the poor people of the locality and the decision of that proceeding usually are not submitted in the court of law, for the implementation, which is the requirement under the Arbitration Act 1940, for the smooth implementation of the decision; through the executive wing of the state. Many countries of the world have amended their arbitration laws, as per the customs and usages of the society and under the light of the relevant International Conventions and Treaties. Similarly, in Pakistan, the Arbitration Act 1940 needs a lot of changes, as per the customs and usages of the society, relevant principles laid down in the Holy Quran and Sunnah of Prophet Muhammad and in accordance with the related International Conventions and Treaties. The UNCITRAL Model Law 1985 is not applicable in Pakistan, thus it is also a requirement and need of the time to be implemented in Pakistan, through the act of the Parliament.
\end{abstract}

\section{Keywords}

Alternate Dispute Resolution, Arbitration, Pakistan, Arbitration Act 1940, Recognition and Enforcement Act 2011 


\section{Introduction}

Pakistan came into being on $14^{\text {th }}$ August, 1947 AD which was $27^{\text {th }}$ day of Ramadan, 1366 AH. It adopted the British Legislated Arbitration Act 1940, which is still applicable in Pakistan. The arbitration is the resolution of an issue; between the contracting parties; outside the court of law, through an arbitrator; who is either appointed by the parties of the contract or by the third party or appointed by the court of law. The disputing parties go for the resolution of their disputes; through the arbitration; because it is not time consuming, not very expensive and the people have confidence on the appointed arbitrator and the process of the arbitration is pure from the technicalities of the procedural law.

"Arbitration is an esteemed system for the concluding and obligatory resolution of differences or arguments, related to an agreement or contract or any other issues linked with an international factor, through an impartial or independent arbitration, in line with mechanism, infrastructure and both legal and non-legal substantive standards; by the parties; either or indirectly" (Lew et al., 2003).

In Pakistan, people usually resolve their disputes outside the court of law, mostly in rural areas of the Federally Administered Tribal Areas, Baluchistan, Sind and Punjab. They follow customs and traditions of their ancestors and they do not follow modern day laws of Pakistan; related to arbitration. Alternate Dispute Resolution in urban areas of Pakistan is not as common as in the rural areas, but arbitrators of urban areas follow modern day laws and submit an award in a court of law for its implementation and the court of the competent jurisdiction passes a decree upon the decision of an arbitrator, if no objection is raised by the contracting parties, within the time specified in the Limitation Act 1908 (Tilmann \& Shinwari, 2015).

Karachi Centre for the Effective Dispute Resolution has been working effectively in the biggest city of Pakistan, Karachi. It is the first Dispute Resolution Institute, which started working in Pakistan. Most commonly used systems of Alternate Dispute Resolution, by the People of Pakistan are, Jirga and Punchayat. Jirga is a dispute resolution system most commonly used by the Pashtu speaking people of Pakistan, they live in the Federally Administered Tribal Areas and in the province of Khyber Pakhtunkhwa. In this system, a dispute is presented before the elders of the area and they decide a dispute through consensus and make a decision of punishment or release. Punchayat is the same system with a same procedure but it is used by the people of the province of Punjab, where the head is called Chaudhry; who rectifies the decision given by the elders. This system is not completely perfect but most people of the vicinity resolve their disputes through this process. People of these traditional systems do not follow the provisions of the Arbitration Act 1940 as they have their own rules and procedure, and it is highly recommended that the Government of Pakistan should amend the current Arbitration Act 1940 or make a new exhaustive arbitration law, to enter their system under the ambit of legislation so that the system would run more smoothly and the decision would then be implemented through the executive wing of the state (Khan, 2004). 
There are arbitrators in urban areas of Pakistan, who follow the provisions of the Arbitration Act 1940 and make awards and submit them in a court of law, for implementation and thereafter parties reach the court of law for the enforcement of an award, normally at the place where an award is made or at the place in whose law is chosen by the parties. Important Pakistani statutes dealing with the arbitration are the Arbitration Act 1940 and the Recognition and Enforcement Act 2011 and the main International Conventions related to the arbitration are the New York Convention 1958 and the UNCITRAL Model Law 1985 (Park \& Yanos, 2006).

The Arbitration Act 1940 is applicable in Pakistan on all types of arbitration proceeding, but the Recognition and Enforcement Act 2011 deals with the recognition and enforcement of International Arbitral Awards in Pakistan. Pakistan has dualism system, it needs a domestic legislation to implement International treaties and conventions. The Recognition and Enforcement Act was passed in 2011, for the implementation of the New York Convention 1958 in Pakistan. The UNCITRAL Model Law 1985 is not applicable in Pakistan because the Parliament of Pakistan has not made it the statute yet. It is highly recommended that the Parliament of Pakistan should implement the UNCITRAL Model Law 1985 in Pakistan as early as possible and do amendments in the current Arbitration Act 1940 and make it a comprehensive statute of arbitration in accordance with the customs and usages of the Pakistani society, principles laid down in the Holy Quran and Sunnah of Prophet Muhammad and under the light of the International Conventions and related Treaties.

\section{Arbitration in Pakistan}

The arbitration in Pakistan is required to be conducted in accordance with the provisions of the Arbitration Act 1940; which was passed by the British Parliament in 1940. It came into force on $1^{\text {st }}$ July, 1940. It has 48 sections; consisted in seven chapters and two schedules. All types of arbitration; in Pakistan; are required to be conducted in accordance with the provisions of the Arbitration Act 1940, if the seat of the arbitration; chosen by the parties; is Pakistan. The purpose of the Arbitration Act 1940 is to consolidate and alter previous enactments and to bring it and to confirm it and to enforce agreed upon stance of the parties of the written agreement and to save the time and the wealth of the parties, by way of resolving disputes through arbitration. The Arbitration Act 1940 is a substantive law; a substantive act normally has a prospective effect, except otherwise expressly mentioned; thus the Arbitration Act 1940 has a prospective effect and not a retrospective effect; it applies to all arbitration proceeding; taken out; after $1^{\text {st }}$ day of July, 1940 in Pakistan.

The concerned High Court of the province in Pakistan may make such rules as are consistent with the Arbitration Act 1940 and the provisions of the Arbitration Act 1940 is binding upon the Federal and the Provincial Governments of Pakistan. Arbitrations covered under the Arbitration Act 1940 in Pakistan are; the arbitration through the intervention of the court; when the suit of the parties is pending before the court of law, the arbitration through the intervention of the court; when parties apply before the 
court of law for arbitration and there is no suit pending between the contracting parties and the arbitration without the intervention of the court of law; which is purely processed in accordance with the will and wishes of the contracting parties of the arbitration agreement (1940).

All provisions of the Arbitration Act 1940 apply upon the arbitration agreement of every kind in Pakistan and no other law can override the arbitration agreement and any person has an objection upon an arbitration agreement may apply before a court of law against its validity. The problem is that the majority people in the rural areas of Pakistan do not follow the provisions of the Arbitration Act 1940 because it contradicts their cultural values and it is against their customs and usages, thus it is the duty of the Government of Pakistan to take them on board and understand their cultural beliefs and amend the current Arbitration Act 1940 in accordance with the customary arbitration practices of the people of the rural areas of Pakistan and to make it under the ambit of the state law, rather than putting them before the wall and taking strict actions against them in localities where the people of the vicinity happy to follow their cultural system of arbitration.

The arbitration is either conducted on the basis of the arbitration agreement or the arbitration clause, both are different in meaning and structure, which is defined by the Sind High Court of Pakistan in a case between MESSRS Crescent Steel and the Allied Products Limited vs. MESSRS Sui Northern Gas Pipeline Limited. The Sindh High Court stated that there is a difference between an arbitration agreement and an arbitration clause. The arbitration agreement is a complete contract on arbitration and the arbitration clause is just a provision in any contract thus it is an underlying contract (2013).

An arbitration agreement must be in a written form, which allows the contracting parties to refer the disputes to an arbitrator, for the resolution of the present or a future dispute; between the contracting parties of the arbitration agreement. The issue is that in rural areas of Pakistan, people do not write any arbitration agreement nor do they put an arbitration clause in an agreement and they just put the matter before the elders of the vicinity; whenever a dispute arises. The Government of Pakistan generally and the superior Judiciary of Pakistan specially are required to resolve this issue and the arbitration should be allowed to be conducted on unwritten contract as well, because when both parties agree on the resolution of their disputes; through the customary system of arbitration; then there is no need to put a compulsory condition that an arbitration agreement and the reference to an arbitrator must be in writing.

Arbitration agreement is an inheritable claim and it does not perish with the party, thus after the death of either of the parties of the arbitration agreement, his legal representatives are required to appear before an arbitrator for the purpose of arbitration and the arbitrator then decides issues between the parties; which are mentioned in a reference; submitted by the parties. If anything is not mentioned in an arbitration agreement; related to the procedure of the arbitration; then an arbitrator must follow the provisions of the Arbitration Act 1940. Parties belong to arbitration agreement are free to enter into any type of agreement, they may make rules for an arbitral tribunal and for arbitrators as well, but if parties 
have not included clauses related to an arbitral proceeding, provisions of the first schedule of the Arbitration Act 1940 would be considered part of the arbitration agreement and required to be applied on an arbitration proceeding in Pakistan. As discussed earlier, usually the people of the rural areas of Pakistan, do not follow the provisions of the Arbitration Act 1940, because it contradicts their customary arbitration system; whose rules and procedure are based upon the customs and usages of the vicinity, and in different parts of Pakistan different rules and procedure are adopted by the people, for the resolution of their disputes, through an arbitration.

An arbitrator is either appointed by the contracting parties or by the court of law or by the third party; who is not a party in the arbitration agreement. When an arbitrator is supposed to be appointed by the third party, the contracting parties are required to provide his name or designation. An arbitrator is a judge in all matters of law and fact and his authority cannot be invoked except if the court of law feels that he has failed to do a reasonable dispatch or if he has misconducted himself or misconducted with the proceeding (1940). Normally, there is only one arbitrator, but parties may appoint more than one arbitrator and when there are two arbitrators, they are required to appoint an umpire and in case of a disagreement between the arbitrators, umpire's decision would be considered final (Won, 2013). This rule is somewhat similar to what is in practice nowadays in rural areas of Pakistan as the decision of the eldest arbitrator is considered final in case of difference between the decision makers.

When parties have failed, for the appointment of an arbitrator, the court of law is required to appoint an arbitrator. People of the rural areas of Pakistan do not go to the court of law, for the appointment of an arbitrator, thus there is a need to amend the current Arbitration Act 1940. When an arbitrator ignores the proceeding or rejects to act or incapable to act or dies, the parties to an arbitration agreement may appoint a new arbitrator in his place.

As per the provisions of the Arbitration Act 1940, arbitrators have four months to announce an award and an umpire has two months to announce his decision. The Sind High Court stated in a case between MESSRS Mechanized Contractors of Pakistan Limited vs. the Airport Development Authority Karachi that the arbitrators are bound to submit an award within four months and an umpire is required to announce his decision within two months or within a prescribed time by the court of law, if they fail to do so, the award would not have any effect (2000). The prescribed time is the maximum time provided for the decision making, the arbitrator may make his award at any time, before the expiration of four months, and an umpire can announce his decision before the expiration of two months or within such extended time as are allowed by the court of law.

When an arbitration proceeding starts, the arbitrator is empowered to summons anything and any person, which has an importance in the arbitral proceeding, and the parties are bound to produce and present them, before the arbitrator. The arbitrator makes a decision which is known as an award. The arbitrator is a sole judge in all matters of law and fact, he has given the powers to take and administer oaths from the contracting parties and from other persons; produced before him as witnesses, he may 
give a preference to the decisions of the court of law, when the question of law is raised in the arbitration proceeding, he can modify the award on his own or on the request of the parties and he can make interrogations with the parties, where necessary (1940).

The arbitrator is required to announce an award; after finishing the arbitration proceeding. An award of an arbitrator must be speaking, which means that there should be solid grounds on which the decision has been made. The award of an arbitrator is conclusive and final and make obligation and it is binding upon the contracting parties and thereafter the parties are required to pay the expenses to the arbitrator and to an umpire (Lyon, 2002).

Remuneration of an arbitrator and an umpire, must be given to them; by the parties; as written in the arbitration agreement or if not written, as directed by the court of law. The Sind High Court stated in a case between MESSRS Mechanized Contractors of Pakistan Limited vs. the Airport Development Authority Karachi that the Arbitrator is being considered a final judge on the question of law and fact, his decision is entitled to utmost respect and weight (2000).

An arbitrator may make an interim award at any time of the arbitration proceeding, and after completion of the arbitration proceeding. Arbitrators, umpire and contracting parties; to an arbitration agreement; are required to sign the award, before submitting it, in a court of law (1940).

After finishing the arbitration proceeding, the announcement of an award and the signature upon the arbitral award, the arbitrator is required to file an award in a civil court of the competent jurisdiction, for making it the rule of the court of law, but in case of the recognition and enforcement of an arbitral award; made outside of Pakistan; parties to an arbitration agreement are required to file an award, before the concerned High Court. The Supreme Court of Pakistan stated in a case between Muhammad Farooq vs. Nazir Ahmed that if neither the time period of arbitration is fixed nor the notice is issued to an arbitrator to enter into a reference and also the defendant denied the execution of an arbitration agreement, the agreement then stands revoked, and the defendant has no authority to stay the proceeding in a suit. The Supreme Court of Pakistan further stated that if the arbitration agreement is void, the arbitration proceeding cannot be held upon a void contract and in case if the award is come out of a void arbitration proceeding, it does not have any effect and the court of law may set it aside. The competent court of the country has the jurisdiction to pass a decree upon the award for its execution and its implementation; it would be considered the determination of the court of law. The Supreme Court of Pakistan further stated that if parties have written that the arbitration agreement does not apply upon a particular difference, the court of law may order that the award would not apply on a particular matter.

An appeal lies before the court of law, upon an order; superseding the award, or upon a special order on an award or upon an order modifying the award or an order; filling or refusing to file an award, or an order; staying or refusing to stay legal proceeding or upon an order for annulment or refusing to annul an award. The court of law has the same power as the arbitrator or an umpire have, for the order of 
appearance and for the establishment of the commission; to examine witnesses; and order to produce documents. The High Court of Azad Kashmir stated in a case between Communication and Works Department vs. MESSRS Design and Engineering System that if there is no irregularity; in respect to the evidence; the court of law does not disturb the decision of an arbitrator but in case where a gross miscarriage of justice is made, the court of law is required to play its part, either modify the award or remit it; partially or wholly; or set it aside (2013).

The registration of an arbitral award is required; after the award becomes the rule of the court of law. The Lahore High Court stated in a case between Haji Ashraf Ali vs. Haji Mushtaq Ali, that the registration of an award is necessary, after it has become the rule of the court of law and not when the arbitrator files it in a court of law, for making it a rule of the court of law (2013).

An award debtor may challenge an award; within 30 days; after its submission, before the court of law (1908). The court of law may modify, remit or set aside an award. If the award has not been challenged, within a prescribed time, the court of law is required to pronounce a judgment, upon an award. If any person obstructs the process of the execution of the decree, the court of law may order an interim injunction; for the implementation of the decree; passed upon the award (1940).

On the request of the parties or on its own, the court of law may modify the award; when some of the part of an award is consisted upon a non-referred issue or when an arbitral award is imperfect due to an error and that error can be modified without affecting the award or if it contains an obvious error or a clerical mistake arising out of an accidental slip or an omission. One case which is related to the modification issue is decided by the Supreme Court of Pakistan between the National Construction Company vs. WAPDA. The Supreme Court of Pakistan stated that when a question is raised; before an arbitrator; that some issues addressed in arbitration are not mentioned in a reference. The court of law held that the arbitrator has misconducted in this case but he has addressed these issues accidently, the court of law is required to modify the award in this case, without affecting the award (1987).

If the modification of the award affects the award, the court of law is required to remit the award to an arbitral tribunal. The court of law is required to remit the award when the arbitrator has undetermined some of the issues referred to him and those are fundamental issues and because of the indetermination, the award is incapable of execution or if the award is illegal on the face of it.

Section 30 of the Arbitration Act 1940 states that: an arbitral award can be declared void by the court of law, if an arbitrator misconducts himself or with the arbitral proceeding or if the award is improperly procured or if the award is made after the order of the court of law; superseding the arbitration; or if the award is made after the arbitration proceeding have become void or if the award is otherwise invalid (1940).

Any party of an arbitration agreement may file an application, for the adjournment of the legal proceeding in a court of law, before filling the written statement, if there is an arbitration agreement between the contracting parties, the court of law is required to send the matter to an arbitrator. Parties 
in a suit; before the court of law; may apply in writing; for arbitration; for all or any of the matter in issue, before the court of law. Thereafter the arbitrator is required to be appointed by the parties and the court of law is required to send a reference to an arbitrator and the court of law does not allow to discuss that issue in a court of law.

The legal proceeding does not affect the reference to an arbitrator, except if the legal proceeding is conducted on whole of the subject matter and the notice is given to an arbitrator or an umpire, in this case, all future proceeding would be invalid, unless the stay of the proceeding is granted. If some of the parties of the suit apply for an arbitration, the award is limited to them only and other parties in a suit are required to appear before a court of law and the award would not be applicable on them. The court of law may; at any time; declare the arbitration agreement void and oblige the parties to appear before the court of law for adjudication of all the disputed issues between the contracting parties (1940).

The issue with the Arbitration Act 1940 is that it does not contain provisions in relation to the dispute resolution proceeding undergone in Pakistani culture and society, thus it is not adopted; as a procedural tool in arbitration proceeding; by the majority of the people of Pakistan, while deciding issues through an arbitration. The customary arbitration system in Pakistani rural areas is very strong and the majority go there with their issues; for the resolution; because it is free of charge and not time consuming, thus it is highly recommended that the Government of Pakistan should amend the Arbitration Act 1940 and make it in conformity with the customs and usages of the Pakistani society, under the light of the relevant principles laid down in the Holy Quran and Sunnah of Prophet Muhammad and as per the related International Conventions and Treaties. The Arbitration Act 1940 is applicable in Pakistan but there are certain laws related to Alternate Dispute Resolution which are only applicable in certain parts of Pakistan, like the Jirga law is applicable in the province of Khyber Pakhtunkhwa and is not applicable all over Pakistan (1977).

The Arbitration Act 1940 deals with the procedure of all kinds of arbitration, whether institutional or non-institutional, it deals with the procedure of the arbitration from the reference till the pronouncement of the arbitral award and submitting it in a court of law, thereafter the Recognition and Enforcement Act 2011 deals with the recognition and enforcement of foreign arbitral awards and Order 21 of the Code of Civil Procedure 1908 deals with the execution of domestic arbitral awards in Pakistan.

The Arbitration Act 1940 does not deal with the recognition and enforcement of arbitral awards made outside the country of execution. Once an award becomes the judgment and the decree of the court of law, it would be considered as it is the decision given by the court of law. The execution of an award would be dealt in accordance with Order 21 of the Code of Civil Procedure 1908.

It is pertinent to mention here that the UNCITRAL Model Law 1985 is a unique International Convention, which deals with the process of arbitration and it is required to be implemented in Pakistan; 
through an act of the Parliament; because Pakistan has dualism system, and it requires an act of the Parliament to implement an International statute on its soil.

The UNCITRAL Model Law 1985 was adopted by the United Nations Commission on International Trade Law on $21^{\text {st }}$ June, 1985. It has 36 Articles, consisted in 8 chapters. The Arbitration Bill 2009 was presented before the National Assembly of Pakistan, for the extension of the implementation of the UNCITRAL Model Law 1985 to Pakistan. The Arbitration Bill 2009 is actually a modified version of the Indian Arbitration Act 1996. Pakistani legislature importing same problems faced by the International Community of Arbitration in India by clearly preventing the application of Part II of the Arbitration Bill 2009 to arbitrations taking place outside of Pakistan. These are the difficulties that Pakistan should seek to evade before the introduction of the new legislation on International Arbitration in Pakistan. It is hoped that these defects in the Arbitration Bill 2009 would be corrected prior to make the Arbitration Bill 2009 an act of the Parliament in Pakistan (2009).

It is pertinent to describe some important provisions of the UNCITRAL Model Law 1985. It states that the arbitration is International when parties habitually resides, carries on business or personally works for gain in two different states. Arbitration agreement is an agreement by the parties to submit; to arbitration; all or certain disputes, which have arisen or which may arise between them, in respect of a defined legal relationship; whether contractual or not. Arbitration is either conducted by the arbitrator or by an organization. Arbitral tribunal is consisted of one or more arbitrators and they are required to file an award in a court of law, after completion of the arbitration proceeding. Each state is required to indicate the court of law or the competent authority to perform the duty of the assistantship and supervision and this authority is given to the concerned High Court in Pakistan.

Parties to an arbitration agreement are supposed to have waived their right to object, if they do not raise an objection upon an arbitral award; within a prescribed time. Parties to an agreement of arbitration are free to determine the number of arbitrators; if not determined by the parties, the number of arbitrators would be three; as per the provisions of the Arbitration Act 1940. Each party appoints a single arbitrator and the two arbitrators are required to appoint an umpire. If parties have failed to appoint an arbitrator; within a specified time of thirty days; or do not come to a consensus on the appointment of the third arbitrator, then the court of law is required to appoint an arbitrator (Neuhaus, 1989). The Court of Quebec, Canada held in a case between the SAURUS INC vs. XPUB Media INC that the court of the competent jurisdiction does not have the special capacity to correct the faulty rule of three arbitrators on ground of cost effectiveness or proportionality (2007).

Appointment of an arbitrator may be challenged if an arbitrator does not possess qualification agreed upon between the contracting parties, in an arbitration agreement or when there are clear doubts on his impartiality. The application for challenging an arbitrator should be made within fifteen days, after the appointment of an arbitrator. The challenging party may request the decision of an arbitral tribunal; before a court of law; within thirty days. If an arbitrator is unable to perform his functions or if he; for 
any other reason; fails to act without undue delay, his mandate would be discontinued. The court of law; has the authority; to decide the mandate of termination, whose decision subject to no appeal, afterwards, a substitute arbitrator would be appointed in his place (1985).

An arbitral tribunal has jurisdiction to start proceeding in accordance with the arbitration agreement or arbitration clause, any objection may be raised but no later than the submission of the statement of defense. If the arbitral tribunal states that it has jurisdiction, any party to an agreement may challenge this statement; within thirty days; before the court of law, whose decision is subject to no appeal.

An arbitral tribunal may make interim orders for the protection of the parties. All parties are required to be treated equally in arbitral proceeding. Parties have right to agree upon the procedure of an arbitral tribunal, failing which the tribunal is required to follow an appropriate procedure. Parties have right to agree upon the place of an arbitration, failing which the arbitral tribunal would determine the place of the arbitration. The arbitral proceeding is required to be started on the date on which a request is received. Parties may agree on the language of the arbitral proceeding, failing which the tribunal is required to decide the language of the proceeding. Unless otherwise provided, either party may amend or supplement his claim or defense, during the course of the arbitral proceeding. The arbitral tribunal is required to decide, whether it holds an oral hearing for the presentation of an evidence or for an oral argument; subject to any contrary agreement between the contracting parties; or whether the proceeding is conducted on the basis of the documents and other materials or not (Herrmann, 1985).

An expert may be appointed by the tribunal to report to it; on specific issues; and the parties are directed to give the expert relevant information or to produce; before it; anything or to provide access to any relevant document. The arbitral tribunal may take assistance; from the court of law; for taking an evidence. The tribunal of arbitration is required to decide the issue in accordance with such rules of law as are chosen by the contracting parties, as applicable to the substance of the dispute. Unless otherwise provided, the decision of the majority of the arbitral tribunal would prevail. If parties settle the issue outside the arbitral tribunal, the tribunal is required to end the proceeding of an arbitration. The decision of an arbitrator is required to be in writing, authorized by the arbitrator and the parties and it would state reasons upon which it is established. The date and place of arbitration must be written and the copy of the decision must be given to each party, after signatures of arbitrators (Sornarajah, 1989).

These are some of the important provisions of the UNCITRAL Model Law 1985, which are not applicable in Pakistan. It is pertinent to mention here that some of the provisions of the UNCITRAL Model Law 1985 are similar to the Arbitration Act 1940 but some provisions are different, which are suitable to be implemented in Pakistan, for the smooth and good arbitration process. Thus, the Government of Pakistan is required and suggested to institute a bill in the parliament, to make the UNCITRAL Model Law 1985 applicable in the territory of Pakistan as well as to amend the Arbitration Act 1940, to make it in inconformity with the customs and usages of the Pakistani society, as per the 
relevant principles laid down in the Holy Quran and Sunnah of Prophet Muhammad and under the light of the related International Conventions and Treaties.

\section{Arbitral Award in Pakistan}

The process of arbitration in Pakistan is required to be conducted in accordance with the provisions of the Arbitration Act 1940 but majority people in rural areas of Pakistan do not follow the provisions of the Arbitration Act 1940, rather they follow their traditional ways to resolve a dispute; which is somewhat similar to arbitration. The award is required to be submitted before the competent court of jurisdiction for its implementation in Pakistan and before the concerned High Court; in case of International Arbitral Award. The law deals with the implementation process of International Arbitral Award; in Pakistan; is the Recognition and Enforcement Act 2011. An ordinance was passed on $14^{\text {th }}$ July, 2005, for the implementation of the New York Convention 1958 in Pakistan by the then Head of the state: General Pervaiz Musharaf. The statute for the Recognition and implementation of the arbitration agreements and foreign arbitral awards in Pakistan was passed on $19^{\text {th }} \mathrm{July}$, 2011. It has ten sections and one schedule, which is consisted of the New York Convention 1958.

Pakistan needs and requires an act or an ordinance; at the national level; to implement International Conventions and Treaties on its soil, because Pakistan has Dualism System. The Recognition and Enforcement Act 2011 was initially an ordinance; which was passed in 2005 and continued to enforce until 2010; thereafter in the reign of Pakistan People's Party; Parliament passed an enactment and converted the ordinance of 2005 into an act of the parliament in 2011, in the reign of President Asif Ali Zardari. Articles of the New York Convention 1958 are mentioned in the Recognition and Enforcement Act 2011, for the purpose of an implementation of the New York Convention 1958 (2011). The New York Convention 1958 is applicable on all states who have ratified it; they all are the contracting states of the New York Convention 1958. The New York Convention 1958 is applicable on the foreign arbitration agreements and the foreign arbitral awards. When foreign parties to an arbitration agreement want an implementation and execution of their foreign arbitral award; which is made in a contracting state of the New York Convention 1958; they may submit an award, an arbitration agreement and the translation in an official language; if the award is in another language; before the respected High Court in Pakistan. The High Court has the jurisdiction to adjudicate and settle matters between the contracting parties and has all the powers of the civil court under the Code of Civil Procedure 1908.

Once accepted the application, the award would have the same effect as a judgment and an order; of a court of law; has in Pakistan. The recognition and enforcement of foreign arbitral awards cannot be refused, except on seven grounds mentioned in article five of the New York Convention 1958 and if there is any inconsistency between the Recognition and Enforcement Act 2011 and the New York Convention 1958, the New York convention 1958 would prevail (2011). 
The question regarding the arbitration proceeding held at International Forum under the New York Convention 1958, was raised before the Supreme Court of Pakistan in a case between Maulana Abdul Haque Baloch vs. the Government of Baluchistan, and the legality of the arbitration agreement was discussed. The court of law held that the Pakistani law is applicable on the arbitration agreement thus the Supreme Court of Pakistan has jurisdiction to decide the legality of the contract (2013).

Any party to an arbitration agreement; after giving notice to the other party; may apply to the High Court for the stay of the proceeding and the court of law is required to refer that matter to an arbitrator. Parties to an arbitration agreement may submit a request for the recognition and enforcement of an award; with a copy of an award and its certified translation and relevant documents; in a court of law. The stay of the proceeding is allowed when the party applies in a court of law for it, but the High Court has some inherent powers under section number 151 of the Code of Civil Procedure 1908 to deny the stay. Application for the stay of the proceeding could not be rejected unless the arbitration agreement is null and void, inoperative or incapable of being performed. If the arbitration agreement is null and void, inoperative or incapable of being performed, the award comes out of the proceeding upon it, does not have any effect (2011).

The actual International Convention, which deals with the implementation of the International Arbitral Award; in member states; is the New York Convention 1958, which was ratified on $10^{\text {th }}$ June, 1958 in New York, the United States of America and entered into force on $7^{\text {th }}$ June, 1959. Pakistan entered into the United Nations in December 1947, all most, Pakistan participated in every major International Treaty of the United Nations and in other Human Rights activities organized under the umbrella of the United Nations. Pakistan ratified the New York Convention in 2005. Pakistan has dualism system that is why it requires an ordinance from the president or an act of the parliament to implement an International Convention or a Treaty on its soil. The New York Convention 1958 is applicable in Pakistan through the Recognition and Enforcement Act 2011.

The New York Convention 1958 is mentioned in the schedule of the Recognition and Enforcement Act 2011. This convention is applicable when contracting parties to an arbitration agreement belong to two different states of the convention. The convention does not apply only to arbitral awards made by arbitrators or umpires but also applies to awards made by arbitral bodies. The convention applies on differences appearing out of a legal connection; contractual or not; in any contractual state (1958). The High Court of Gujarat, India stated that the question, whether the party belongs to the New York Convention 1958 or not, is to be determined by the reference at the time of the proceeding for the enforcement rather than by the reference on the date of an award. Parties may resolve their all or some of the differences if they are capable of being arbitrated under the New York Convention 1958. The New York Convention 1958 is applicable on an arbitration agreement as well as on an arbitration clause; they all are called agreements in writing.

The arbitral award is as binding in the vicinity of the contracting state as it is the rule and procedure of 
that state. The state cannot charge a higher fee or charges for the enforcement of foreign arbitral awards than the enforcement of domestic arbitral awards; in another words, there is no difference; in respect to charges; between the recognition and enforcement of a local arbitral award and the recognition and enforcement of an international arbitral award. The party to an arbitration agreement applies for the recognition and enforcement of an arbitral award, is required to submit the award in the High Court with the arbitration agreement and if both documents are in any other language, the translation of documents; is required; in official language as well. Translation must be certified by an official authority or a sworn translator or by a diplomat or a consular agent (Albert Jan Van den Berg \& Haag, 1994).

The recognition and enforcement of an arbitral award can be refused if the parties to an arbitration agreement do not have the capacity to enter into an agreement or if the arbitration agreement is void or if the party against whom the award is invoked is not in a notice to it or if the award contains things which were not referred to an arbitrator for an arbitration or if the arbitral award is declared void by the competent authority or if the dispute between the contracting parties is not allowed to be arbitrated or if the award is not in consistent with the public policy. The court of law may; with the adjournment of the order of the recognition and enforcement, on the request of the side claiming enforcement; order the other party to provide a suitable security (1958).

Article 07 of the New York Convention 1958 states that the New York Convention 1958 does not affect any treaty between the contracting states nor does it affect any right which a party may avail under a domestic legislation. In view of this article, an aggrieved party has six grounds available; in Pakistan; for challenging an arbitral award under section 30 of the Arbitration Act 1940. Any state may take reservation that the convention may apply on some parts of its territory and not on all parts of the territory. The reservation request should be addressed to the secretary general and may take effect after eighteen days of receiving to the secretary general or on the date when the convention came into force at its territory; whichever is later. Each state is required to take necessary steps to enhance the application of the New York Convention 1958. A federal state party to the New York Convention 1958 provides a statement of the law and practice of the federation and its electoral units with regard to any special provisions of the New York Convention 1958, showing the extent to which effect has been given to that provision by legislative or other action. Any contracting state may condemn the New York Convention 1958, through a written notification to the secretary-general of the United Nations. Opting out from the convention takes effect after expiration of one year from the date of receiving of the notification by the secretary-general. It is pertinent to mention here that the member state; who declares a denunciation; does not use that denunciation against other states (Domenico Di Pietro \& Platte, 2001).

Pakistan should have been the party earlier on but Pakistan ratified the New York Convention in 2005. Somehow the New York Convention 1958 is applicable in Pakistan through an act of the Parliament. 
The New York Convention 1958 does not stop parties to an arbitration agreement to avail rights mentioned in the Arbitration Act 1940 thus the contractual parties to an agreement of arbitration in Pakistan may avail the remedies of modification, remission and annulment of an award mentioned under section 30 of the Arbitration Act 1940.

\section{Judiciary of Pakistan}

Pakistan has one Supreme Court, situated in the capital territory of Islamabad. Five High Courts; four situated in four provinces and the fifth one is situated in Islamabad; for the people of the federal territory Islamabad. Lahore High Court situates in Lahore for the people of the Punjab province, Peshawar High Court situates in Peshawar and works for the people of the province Khyber Pakhtunkhwa, Sindh High Court is the High Court of the province of Sindh; which situates in Karachi and Baluchistan High Court situates in Quetta (Hussain, 2011).

As per the provisions of the Recognition and Enforcement Act 2011, an arbitral award; which is made outside Pakistan and whose execution and implementation is sought in Pakistan; is required to be submitted before the respected High Court; in whose jurisdiction the implementation is sought (2011). An aggrieved party may challenge the decision of the High Court before the Supreme Court of Pakistan.

Apart from a Supreme Court of Pakistan and five High Courts of Pakistan, there are two types of courts in Pakistan: The Civil Court and the Criminal Court. The criminal court system is divided into Sessions Judges and Magistrates. There are three categories of magistrates in Pakistan: Magistrate $1^{\text {st }}$ Class; who can announce punishment of imprisonment up-to three years and 15,000/- fine, Magistrate $2^{\text {nd }}$ Class; who can announce punishment up-to one-year imprisonment and 5,000/- fine and Magistrate $3^{\text {rd }}$ Class; who can announce punishment up-to one-month imprisonment and 1,000/- fine (1898). Every District has a Sessions Judge and if a district is divided into more than one part, every part has one Sessions Judge, several additional and assistant Sessions Judges are appointed for the resolution of criminal disputes and several civil judges are appointed for the resolution of civil disputes.

There are three categories of civil judges in Pakistan: Civil Judge $1^{\text {st }}$ Class; whose pecuniary jurisdiction is unlimited, except three million in Karachi and Islamabad, Civil Judge $2^{\text {nd }}$ Class; whose pecuniary jurisdiction is 0.5 Million in Punjab province, fifty thousand in Sindh and Khyber Pakhtunkhwa provinces and fifteen thousand in Baluchistan province and Civil Judge $3^{\text {rd }}$ Class; whose pecuniary jurisdiction is 0.1 million in Punjab province, 25 thousand in Sindh province, 20 thousand in Khyber Pakhtunkhwa province and 5 thousand in Baluchistan province.

The domestic arbitral award of Pakistan is required to be submitted in a concerned Civil Court, as per the provisions of the Arbitration Act 1940, for its smooth implementation under Order 21 of the Code of Civil Procedure 1908, but; as already discussed; the majority people of the rural areas of Pakistan do not follow the provisions of the Arbitration Act 1940 as they have their own customary practices, 
which is suggested to be made under the ambit of law after consultation with the people of the vicinity, for the betterment of the arbitration system of Pakistan to create a strong enforcement structure of the arbitration in Pakistan.

It is pertinent to mention here that Pakistan is an Islamic State (1973), where more than 97\% of the population is Muslims, apart from the traditional customary practices for the resolution of their disputes, the people of Pakistan try to follow the principles laid down in the Holy Quran and Sunnah of Prophet of Muhammad, as laid down in the Holy Quran and in the Sunnah of Prophet Muhammad. While amending the Arbitration Act 1940, the Government of Pakistan is suggested to take into account the relevant principles laid down in the Holy Quran and Sunnah of Prophet Muhammad, the customary practices of the rural areas of Pakistan and the latest International Conventions and Treaties.

\section{Conclusion and Recommendations}

The arbitration frame work in Pakistan is mainly consisted of the Arbitration Act 1940 and the Recognition and Enforcement Act 2011; which contains the New York Convention 1958. One of the problems of the arbitration system of Pakistan is that the UNCITRAL Model Law 1985 and other related International Conventions and Treaties are not applicable in Pakistan and there is a need that the relevant International statutes should be implemented in Pakistan through an act of the parliament as Pakistan has dualism system which requires a domestic legislation to implement an International statute on its soil.

The Arbitration Act 1940 deals with the process of the arbitration and the Recognition and Enforcement Act 2011 deals with the implementation of Foreign Arbitral Awards in Pakistan. The New York Convention 1958 deals with the recognition and enforcement of a decision of an arbitrator, pronounced in one of the contracting states and the UNCITRAL Model Law 1985 deals with the process of an arbitration.

The Recognition and Enforcement Act 2011 suggests a party; who wants an implementation of an arbitral award; made outside of Pakistan; to apply for its recognition and enforcement before the concerned High Court in Pakistan. The Recognition and Enforcement Act 2011 is a special law and the Arbitration Act 1940 is a general law and when there is a contradiction between a special law and a general law, the special law would prevail. Moreover, the recent law on the subject matter has priority over the previous enactment. When there is a contradiction between the Recognition and Enforcement Act 2011 and the New York Convention 1958, the New York Convention 1958 would prevail.

The domestic law of arbitration in Pakistan is the Arbitration Act 1940. Article 07 of the New York Convention 1958 states that the New York Convention 1958 does not nullify any right, which is available; for the aggrieved party; under any domestic statute of the arbitration, thus the grounds available for the modification, remission and setting aside an award; under section 30 of the Arbitration Act 1940; are applicable on all types of arbitral awards in Pakistan. 
An arbitrator is required to file an award; before a concerned court of law; for its implementation in Pakistan but the majority people of the rural areas of Pakistan decide their disputes through the traditional arbitration process and they do not follow the provisions of the Arbitration Act 1940 and they do not submit their arbitral awards before a court of law for their implementation.

As per the provisions of the Arbitration Act 1940, the parties to an arbitration agreement may apply before an arbitrator or before a court of law for the correction of an award; if there is any clerical mistake or a typographical error; and then the court of law may modify the award but if the error cannot be modified because in the case of the modification, the subject matter of an arbitral award effects or if the arbitrator has not considered all the matters and issues referred to him in a reference, the court of law would remit the matter to an arbitrator for correction or may set it aside itself; if the arbitrator misconducts himself or with the arbitration proceeding; or if the other party has improperly procured the award, or if the award is taken after the order of the court of law that the arbitral proceeding is null and void. The UNCITRAL Model Law 1985 does not apply in Pakistan thus the aggrieved party may not avail the grounds mentioned in the UNCITRAL Model Law 1985 for setting aside an arbitral award and for the rejection of an implementation of an arbitral award.

It is pertinent to mention here that the court of law is required to go towards acceptance rather than rejection of an arbitral award, but it has powers of modification, remission and setting aside an award. The arbitrator is considered a final judge on the question of law and fact, his decision is entitled to utmost respect and weight. If the award is not challenged within a specified time, the court of law is required to issue a decree upon the award and that decree would be considered a final decision of a court of law and would be implemented and enforced in Pakistan under Order 21 of the Code of Civil Procedure 1908.

In view of the above discussion, it is recommend that the Parliament of Pakistan should amend the Arbitration Act 1940 and insert some useful provisions in accordance with the customs and usages of the Pakistani culture and society, in light of the relevant principles laid down in the Holy Quran and Sunnah of Prophet Muhammad while keeping in mind the present structure of the arbitration in the rural areas of Pakistan, to minimize the gap between the people of the rural areas and the urban areas of Pakistan and once the people of rural areas come under the ambit of the Arbitration Act 1940, the Justice System of Pakistan would become more strong and it would enhance the confidence of the people upon the Government of Pakistan generally and upon the Judiciary of Pakistan particularly. It is also suggested that the Parliament of Pakistan should pass a domestic legislation to make the UNCITRAL Model Law 1985 applicable in Pakistan so the aggrieved party may avail more grounds for setting aside an arbitral award and for challenging the implementation of an arbitral award in Pakistan.

It is also suggested that normally the arbitration agreement and the arbitration clause and the reference to the arbitrator are required to be made in writing; which is a requirement under the law; which should 
be amended and a relaxation should be given to the people of Pakistan at large, that the people should be allowed to process an arbitration proceeding upon an oral arbitration agreement and an arbitration clause and an oral reference should be allowed to be made to an arbitrator to start the arbitration proceeding. This relaxation should be especially made for the people of the rural areas of Pakistan, where parties normally are uneducated, as the overall literacy rate of Pakistan is only $60 \%$.

It is also recommended that the Government of Pakistan should make efforts to convince the people of the rural areas of Pakistan to follow the provisions of the Arbitration Act 1940 and to submit their decisions in the concerned court of law for its smooth implementation and for that purpose it is appropriate that the members of the federal and provincial legislatures; belong to the vicinity; play their vital role. It is also suggested that the leaders of the rural areas should be consulted for the amendments and changes in the current legal framework of arbitration in Pakistan and the arbitration procedure of the rural areas of Pakistan should be covered under the ambit of the law of Pakistan rather than pushing them before the wall and giving them an opportunity to make a parallel system of dispute resolution.

Pakistan in an Islamic country and there are various mosques and religious institutes which can be used as the dispute resolution places, if the scholars participate in the dispute settlement process and start resolving disputes of the general people of the vicinity. It is suggested that the Government of Pakistan should encourage Islamic Scholars to enter into the arbitration process and provide their services for the effective establishment of the arbitration system in Pakistan. Islamic Scholars may provide their services at different mosques and in religious institutes, free of charge or on payment of a little amount or even the Government of Pakistan may provide them salaries and give them tasks to help the people of Pakistan to resolve their disputes through arbitration.

\section{References}

Albert Jan Van den Berg, \& Haag, T. D. (1994). The New York Arbitration Convention Of 1958: Towards A Uniform Judicial Interpretation. Kluwer.

Domenico Di Pietro, \& Platte, M. (2001). Enforcement of International Arbitration Awards: The New York Convention of 1958. Cameron May.

Haji Ashraf Ali VS Haji MUSHTAQ Ali. (2013). Civil Law Digest. The Lahore High Court: 604.

Herrmann, G. (1985). The UNCITRAL Model Law, its Background, Salient Features and Purposes. Arbitration International, 1(1), 6-39. http://dx.doi.org/10.1093/arbitration/1.1.6

Hussain, F. (2011). The Judicial System of Pakistan. Supreme Court of Pakistan.

Khan, M. A. (2004). Pakistan: Legality of a Hisba Bill to introduce an Islamic Ombudsman in the North-Western-Frontier Province. YB Islamic \& Middle EL, 11, 413.

Lew, J. D. et al. (2003). Comparative International Commercial Arbitration. The Hague/London/New York, Kluwer Law International. 
Lyon, S. (2002). Local Arbitration and Conflict Deferment in Punjab, Pakistan. Anthropologie, 40(1), 59.

MAULANA Abdul HAQUE Baloch VS the Government of BALOCHISTAN. (2013). Pakistan Law Digest. The Supreme Court of Pakistan 641.

MESSRS Crescent Steel and Allied Products Limited VS MESSRS Sui Northern Gas Pipeline Limited. (2013). Monthly Law Digest. The Sindh High Court: 1499.

MESSRS Mechanized Contractors of Pakistan Limited VS Airport Development Authority Karachi. (2000). Civil Law Cases. The Sindh High Court: 1239.

Muhammad, F., \& Nazir, A. (n.d.). Pakistan Law Digest. The Supreme Court of Pakistan: 196.

Neuhaus, J. E. (1989). A Guide to the UNCITRAL Model Law on International Commercial Arbitration: Legislative History and Commentary. Kluwer Law International.

Park, W. W., \& Yanos, A. A. (2006). Treaty Obligations and National Law: Emerging Conflicts in International Arbitration. Hastings LJ, 58, 251.

Sornarajah, M. (1989). The UNCITRAL Model Law: A Third World Viewpoint. Journal International Arab, 6, 7 .

The Arbitration Act. (1940). Islamic Republic of Pakistan. X.

The Arbitration Bill. (2009). Islamic Republic of Pakistan.

The Code of Criminal Procedure. (1898). Islamic Republic of Pakistan. V.

The Communication and Works Department VS MESSRS Design and Engineering System. (2013). Civil Law Digest. The High Court of Azad Kashmir: 1438.

The Constitution of Islamic Republic of Pakistan. (1973). Islamic Republic of Pakistan.

The Limitation Act. (1908). Islamic Republic of Pakistan.

The National Construction Company VS Water and Power Development Authority. (1987). Pakistan Law Digest. The Supreme Court of Pakistan: 461.

The New York Convention. (1958). United Nations.

The North West Frontier Province Civil Procedure (Special Provisions) Act. (1977). Islamic Republic of Pakistan.

The Recognition and Enforcement Act. (2011). Islamic Republic of Pakistan.

The SAURUS INC VS XPUB Media INC CANL II. (2007). The Court of Quebec, Canada 10436.

The UNCITRAL Model Law. (1985). United Nations.

Tilmann, J. R., \& Shinwari, N. A. (2015). Pakistan: Jirgas Dispensing Justice without State Control. Non-State Justice Institutions and the Law, Springer, 25-54.

Won, S.-K. (2013). Overview of Alternate Dispute Resolution with Special Reference to Arbitration Laws in Pakistan. Journal of Arbitration Studies, 23(3), 149-167. http://dx.doi.org/10.16998/jas.2013.23.3.149 